\title{
Deforestation and the Social Impacts of Soy for Biodiesel: Perspectives of Farmers in the South Brazilian Amazon
}

\author{
Mendelson Lima $^{1}$, Margaret Skutsch $^{2}$, and Gerlane de Medeiros Costa ${ }^{1}$
}

\begin{abstract}
Cultivation of soy for human and animal food has been growing rapidly in Brazil in the last thirty years, and the recent emergence of a biodiesel market in Brazil has stimulated this further. Soy occupies large parts of the Cerrado biome and has now reached the Amazon, and concerns have been raised about both the environmental and social impacts of this. This study combined data from literature with interview surveys in three areas in the soy belt: Sorriso, in the Cerrado; Guarantã do Norte and Alta Floresta, in the transitional zone between the Cerrado and the Amazon biome, and Santarém, which is fully in the Amazon biome, to understand these impacts from the perspective of the soy farmers, the other farmers, and the laborers. From the literature it is clear that at least $80 \%$ of the direct deforestation is due to clearance for cattle rearing, and we estimate that $13-18 \%$ is due to soy, although less than $6 \%$ can be attributed to biodiesel, since most soy is used for other products. In the Amazon biome, the Forest Law, the Soy Moratorium, improved monitoring and the general unsuitability of the land have combined to keep soy cultivation at a low level so far despite the construction of a port at Santarém, which makes this area much more accessible. In the site in the transition area little soybean is cultivated due to unsuitable configuration of land and to transportation costs. In the Cerrado, however, soy has proved itself to be a viable alternative to timber, as well as replacing grazing, which is most likely causing indirect deforestation elsewhere, although this effect could not be measured in this study. More than half of the soy farmers interviewed claimed to have converted grazing land as opposed to forest, although grazing land often contains some secondary forest as well as grassland. In the transition areas, the expectation of farmers is that when transport costs fall due to road improvements, soy will be cultivated in an integrated rotation system on grazing land, improving degraded pastures. Soy farmers, laborers and non-soy farmers all have a positive view of the social impacts of soy, borne out by the fact that average incomes in Sorriso, where there has been an enormous increase in soy production over the last 20 years, are 4.6 times higher than those in Guarantã do Norte, which is still dominated by cattle rearing. The PNPB program, which aims for social inclusion of small family farmers in the production of biofuel feedstock, has succeeded in forcing large soy purchasing companies to assist essentially uneconomic farms and has enabled some small farmers in agrarian reform settlements to profit. However, we found evidence of plots changing hands and being consolidated by farmers with greater skills and capital, resulting in incipient class formation. Moreover, the companies are selective in their choice of agrarian settlement, and were not operating in those in which land holdings are very small or where the terrain is too broken up for large-scale mechanization.
\end{abstract}

Key Words: Amazon; biodiesel; deforestation; family farmers; social impacts; soy

\section{INTRODUCTION}

The role of biofuels in the mitigation of climate change is highly contested. A key issue is the extent to which biofuels will reduce carbon dioxide emissions if the cultivation of their feedstocks results in clearance of stocks of carbon from forests (deforestation). Associated with this are questions about the loss of locally valuable forest goods and services. If cultivated land is used instead, there is a potential loss of food production and reduced food security, and there are risks that any form of biofuel production may change traditional land holding patterns, social relations, and livelihood opportunities, particularly if large-scale production replaces small-scale farming.

Three cases are presented here, each of which concerns the environmental and social impacts of biodiesel as a relatively new and additional product from soy, in a different part of the south Brazilian Amazon. Our principal aim is to complement the information available in the literature with perspectives of the local farming population with regard to the following questions: (1) has the opening of a market for biodiesel increased the level of deforestation caused by soy? (2) if so, what are the implications with regard to forest goods and services for local populations? and (3) what impact has this development had on access to land, employment and general well-being?

A clarification first needs to be made in terms of what is meant by the "south Brazilian Amazon". The Amazon biome represents the humid tropical forest area and areas which are transitional to the Amazon forest. The Legal Amazon is a Brazilian administrative area, which includes the entirety of the states of Acre, Amazônia, Rondônia, Roraima, Amapá, Pará, Mato Grosso and most of Tocantins and Maranhão, and represents $61 \%$ of Brazil's territory. Not all of this area is in the Amazon biome, and in particular, about half the territory

${ }^{1}$ Departamento de Ciências Biológicas, Universidade do Estado de Mato Grosso, ${ }^{2}$ Centro de Investigaciones en Geografia Ambiental, Universidad Nacional Autonoma de Mexico 
of Mato Grosso is Cerrado (savanna forest). Our study focused on the impacts of soy cultivation in three distinctly different ecological zones within the Legal Amazon south of the Amazon river, and included one site in the Cerrado zone near Sorriso, one in the transitional area around Guarantã do Norte and Alta Floresta (these sites are within the state of Mato Grosso), and one in an area of cleared Amazon rainforest near Santarém (Pará state).

The article is structured as follows. Firstly, a number of key policies that have influenced the development of biodiesel and expansion of soy production in Brazil are briefly explained. Secondly, relevant literature is reviewed on three contested themes of relevance: the extent to which soy cultivation is resulting in deforestation, the positive and negative social impacts of soy cultivation, and whether the Brazilian biofuel program has succeeded in its aims of social inclusion. Thirdly, the methodology used in the field studies is presented, starting with a description of the three study areas. Fourthly, the results are presented in terms of perception of respondents as regards environmental and social impacts and finally, conclusions are provided.

\section{Brazilian policy of relevance to the case}

Brazil is a major world player in biofuels, and has had a sugar ethanol program since 1975. In 2003, a National Biodiesel Production Program (PNPB) was initiated with a view to achieving several objectives simultaneously: reduction of diesel imports, promotion of the economy though development of a market for a variety of oil bearing crops in different regions, reduction of diesel prices through competition, and the promotion of social inclusion of the agricultural labor force, in other words the involvement not only of large commercial companies but also of small "family farmers" in cultivation of feedstocks. Particularly on account of this last point, the Brazilian Biodiesel Program has been the subject of considerable scrutiny and critique (Hall et al. 2009, Andrade and Miccolis 2010, Fernandes et al. 2010, Weinholt et al. 2010, Hospes and Clancy 2011).

Biodiesel from a variety of oil bearing plants (soy, castor, sunflower, palm-oil) is sold primarily in the national market rather than exported, and this is stimulated by blending targets which have risen from 2\% in 2008 to $5 \%$ in 2010 (ANP 2010). At present, $78 \%$ of the total feedstock for biodiesel comes from soy, mainly from Mato Grosso and Mato Grosso do Sul and $18 \%$ from animal fats, although soy's contribution is expected to rise to $90 \%$ in the near future (Wilkinson and Herrera 2010), meaning that soy interests dominate the politics of biodiesel. Most soy is produced on large, commercial farms (2,000 ha is considered a small commercial farm and $40.5 \%$ of the farms that produce soy in Mato Grosso are between 1,000 to 9,999 hectares, according to Conte 2006), and production is highly capital intensive. Under the PNPB, however, the so-called Social Fuel Stamp was introduced, such that biodiesel companies must purchase a minimum quantity of their feedstock from so-called family farmers $(<100$ hectares in Mato Grosso) if they are to participate in government auctions, which are the primary market for biofuel in the country. This proved a strong incentive, forcing companies to engage with the family farming sector despite the much higher costs involved. They may also benefit from tax exemptions ranging from $4-12 \%$ of the commercial price of diesel, depending on the location of the feedstock purchases (Hall et al. 2009; La Rovere et al. 2011). The quota for purchase from family farmers in Mato Grosso was 10\% in 2009/2010 and $15 \%$ in 2010/2011 (MDA 2010). The companies are also required to provide technical assistance and credit to smallscale farmers who would otherwise lack the capital to rent machinery or purchase inputs in the open market.

To meet these criteria, some companies have established partnerships with small farmers in agrarian reform areas set up by INCRA (National Institute of Colonization and Agrarian Reform). INCRA has resettled landless farmers from poorer areas (north and south of Mato Grosso) in the soy belt around Sorriso, using cattle ranches that have gone bankrupt. Typically such an estate will be broken up into lots of 40 to 100 hectares, which means that the new settlers qualify under the PNPB, if they chose to grow soy. For reasons of efficiency, companies purchasing with a view to production of biodiesel tend to "adopt" clusters of farmers in such settlements. It should be noted, however, that soy is primarily grown for cattle fodder and food; when processed, it produces meal (cake) and oil, but only the oil can be used to make biodiesel. Moreover, much of the oil is used for products such as margarine. The farmer does not know what products his soy will be used for, and the companies make the split depending on spot prices.

In terms of the deforestation that takes place as a result of soy production, the Brazilian Forest Code sets limits on the amount of forest that can be cleared within any plot of land. The 1965 Code (Law 4.771/65) was amended in 2001 (MP 2.166/67), making it a legal requirement that $80 \%$ of each parcel within the Amazon biome must remain forested (Legal Reserves), which means that soy farming will be much less profitable here than in the Cerrado, where only $35 \%$ of native vegetation cover has to be retained. In addition, Areas of Permanent Preservation (APP) are designated in vulnerable areas, such as along rivers, hilltops, and steep slopes. In the last few years, enforcement of the Forest Code has been substantially strengthened, partly as a result of improvements in the ability to monitor forest cover through remote sensing. However, the policy is not popular with soy producers who are exercising political pressure to get it changed. A recent motion passed in the Senate regarding "reform" of the Forest Code, primarily to reduce the APP requirements along rivers from 30 to 15 meters and to allow these areas to count as part of the Legal Reserves, which is not the case at the moment (Metzger et al. 2010). This would have a serious impact on environmental 
connectivity and water catchment (Michalski et al. 2010); a decision on the matter has yet to be taken by the Federal Assembly. Proposals to reduce the size of the Legal Reserve quota in the Amazon biome, and for amnesty for those who deforested illegally before July 2008, have also been made. The expectation of increased flexibility has stimulated a substantial increase in deforestation rates inside the Legal Amazon region. Between March and May of 2011 alone, 860.9 $\mathrm{km}^{2}$ of forest were cleared, with deforestation in the areas of soy and cattle-raising of Mato Grosso answering for $67 \%$ of the total. This is $500 \%$ more than in the similar period of the previous year, according to Adario (2011). The matter still has to be voted in the Brazilian Congress, however, and faces a possible Presidential veto, so the outcome is still in the balance.

An important development related to this is the Soy Moratorium. Established in July 2006 after a vigorous international campaign by Greenpeace, this has been a unique experience in which the productive sector and environmental groups aimed to reconcile economic development and socioenvironmental conservation in the Amazon biome. It first involved a two-year commitment by the main players in the industry not to purchase soybeans cultivated on any land in the Amazon biome that had been illegally deforested after 2006, in other words, not to buy from farmers who had cut more than the allowed quota of forest in order to plant soy. A working group known as GTS (Working Group on Soybean) was formed, composed of commercial associations such as ABIOVE (Brazilian Association of Vegetable Oil Industries) and ANEC (Brazilian Association of Grain Exporters), companies (ADM, Amaggi, Bunge and Cargill), the Bank of Brazil, and civil society organizations such as Conservation International, Greenpeace, IPAM, TNC and WWF Brazil. Between 2007 and 2009, the GTS promoted the monitoring of deforestation in municipalities with over 5,000 ha of planted soybean in the states of Mato Grosso, Pará and Rondônia. Planting of soybean in illegally deforested areas was identified on 12 properties, totaling 1385 ha or less than $1 \%$ of the monitored area, showing that soy was hardly responsible for deforestation in the biome during that period, as a result of this voluntary agreement. The moratorium has been extended annually with the participation of the Ministry of Environment (ABIOVE 2010), and monitoring now uses finer resolution images, which enable identification of smaller scale clearances. The area deforested for soy in 2010 corresponded to only $0.25 \%$ of the deforestation that occurred in the Amazonian biome in the states of Mato Grosso, Pará and Rondônia, which totaled 2.49 million ha over the years 2007-2009. However, most of Brazil's soy production is located in the Cerrado, and is therefore not included in the Soy Moratorium.

Another policy tool being used to limit deforestation is access to bank credit. Law No. 6.938 of August 31, 1981 suspends credit lines for those shown to have practiced illegal deforestation. The law is strengthened today by the intensification of the monitoring and computerization of information, and the availability of remotely sensed images in particular. Credit is only released after checking by the environmental agencies that the property shows no irregularity in terms of the environment. In Guarantã do Norte, for example, a property we visited could not obtain credit from the Bank of Brazil because it had appeared on the website of SEMA (the Secretariat for the Environment), for an irregular clearing of 97 hectares. Previously the banks had no mechanisms for verification and had to accept documents produced by the owner as regards compliance of his property. Access to credit is also linked to tenure, both for small and large producers. There are of course opportunities for, and anecdotal stories about, corruption at the individual level, but there is no doubt that these policies have had some effect on limiting illegal deforestation.

\section{Claims and counterclaims regarding soy, biodiesel, and deforestation}

Three discourses are of interest as background to the case study we present. The first concerns evidence for the extent to which deforestation is being caused by the expansion of soy, the second concerns the social impacts of this expansion, and the third, the effectiveness of the PNPB in terms of social inclusion.

\section{Evidence for soy-related deforestation}

Soy was first planted in southern Brazil at the beginning of the last century, and it expanded during the 1960s from the south to the north of Paraná in the Atlantic Forest. The military government of the time (1964-1984) was pursuing policies ("Integrar para não entregar") to open up Central Brazil, including the south Brazilian Amazon. As roads were built, waves of migrants from southern and southeastern regions of the country arrived, attracted by the low price of land, the government policy of donating land to individuals, and the assistance of large corporations. New agribusinesses, particularly meat and logging industries, brought hundreds of thousands of new farmers to the region. In the 1980s and 1990s, soy production expanded rapidly, particularly in the Cerrado zone (Myers et al. 2000, Amaral et al. 2005). From 1990, soy began to encroach upon the transition zone between the Cerrado and the Amazon biome to the north, reaching the Amazon river itself around 2000. In Mato Grosso, the heartland of soy production, the area devoted to soy has increased fourfold in the ten years since 2000 (Wilkinson and Herrera 2010). Thus while the Soy Moratorium and Forest Code enforcement may have substantially lowered soy-related deforestation in the Amazon biome, the same is not true throughout all the Legal Amazon.

According to Barreto et al. (2005), the process of occupation resulted in deforestation of $11 \%$ the Legal Amazon between 
1970 and 2001. Average annual deforestation levels were approximately $15,000 \mathrm{~km}^{2}$ from 1978 to 1988 (Skole and Tucker 1993), and 17,691.5 km² from 1989 to 2007 (INPE 2010). The question of how much of this deforestation has been caused by soy production for biodiesel is however disputed, since although there is a strong correlation between loss of forest and area planted with soy (Carvalho et al. 2002, Bickel and Dros 2003, Fearnside 2005), a large proportion of this may have been caused in the first instance by clearance for grazing or for other crops, as argued for example by Brandão et al. (2005) and Goldemberg and Guardabassi (2009). It should be noted that soy is not usually planted immediately after clearance of the forest plot, even when the intention in the long run is soy cultivation. Most soy producers cultivate rice in the first one or two years because it is easier to convert the land that way for technical, machine-related reasons. Using a new FAO data set, Gibbs et al. (2010) have established that the clearance in the Amazonian "arc of deforestation" between 1980 and 2000 involved large areas of intact, undisturbed forest but they did not distinguish the proportion of loss due to cultivation (which is mainly soy) versus grazing. Moreover, as we will elaborate, only a small proportion of the soy is actually used to produce biodiesel, the bulk of the crop being processed for cattle feed and human consumption, so by no means all soy-related deforestation can be laid at the door of biodiesel.

Brown et al. (2005) studied land cover change in Rondônia during the second half of the 1990s and found that most soy expansion was on land already cleared for pasture. Morton et al. (2006) worked with data on large scale ( $>25$ ha) forest clearing events from 2001 to 2004 in the southern Brazilian Amazon and showed that cropping was accountable for $16 \%$ of forest clearance in this area, while the rest (i.e., the majority) was due to cattle ranching. They did, however, identify a general relationship between the price of soy and deforestation rates. They noted also that areas cleared for cropping were on average larger than those for grazing and were concentrated primarily along BR 163 , which runs $1,700 \mathrm{~km}$ from Cuiabá in the south to Santarém on the banks of the Amazon. Barona et al. (2010) looked at the whole Legal Amazon between 2000 and 2006 and found that most $(84 \%)$ of the deforestation occurred in Pará, Mato Grosso, and Rondônia in this period. Pasture area decreased in several areas including southern Mato Grosso, but increased in the interior of the Amazon, and overall deforestation rates correlated much better with expansion of pasture than with expansion of cropland. Their conclusion is that pasture is being displaced northwards in a process of indirect deforestation driven by soy expansion. They note that a contributing factor might be economic feedback links between soy and cattle, resulting in larger herd sizes. This theory of indirect deforestation in the Amazon is supported by the spatially explicit simulation model developed by Lapola et al. (2010). The question of indirect impacts of biofuel on land use change (ILUC) is one of considerable contention, but as this discussion indicates, there are important interfaces between different sectors. The simplistic conclusion that soy, and in particular soy for biofuel, is responsible for the problem needs to be examined in the light of the complexities of regional land use dynamics and regulatory frameworks more generally, including, for example, an analysis of the reasons for the recent escalation of investment in beef production. Such an analysis is unfortunately beyond the scope of the present paper.

Looking to the future, Vera-Diaz et al. (2009) modeled the possible expansion of soy based on spatial estimates of transport costs, which account for about $30 \%$ of the total cost of production at present. Paving of the northern part of BR 163 from Guarantã do Norte to Santarém (nearly 1,000 km) is planned and should both lower the costs of road transport and shorten the sea voyage to Europe and the USA. Vera-Diaz et al. estimate that it would increase the economically feasible area of soy production from 120,000 to $205,000 \mathrm{~km}^{2}$, mostly in Pará, although not all of this is in forested areas. However, this study was based purely on the economics of transport. In practice, large parts of this northern zone are not well suited to soy cultivation because the land is broken up by small streams and hills which restrict mechanization. Moreover, the Soy Moratorium is currently in force in this area, with the result that enforcement of the Forest Code has been substantially strengthened. Nepstad et al. (2009) are of the opinion that stopping deforestation in the Amazon region is now within the bounds of the possible, with strong government commitment to this goal under UNFCCC. Given the share of forest clearance that can be attributed to cattle rearing, intensification of beef production may be an even more important instrument in achieving this goal (Lapola et al. 2010).

The studies that have been quoted all refer either to deforestation due to agricultural expansion in general or to soy in particular; however, as noted earlier, only a small portion of total soy production is used for biodiesel. To get a sense of the burden of deforestation attributable to biodiesel, we must start from the fact that at least four-fifths of direct deforestation in the Amazon region is due to pasture expansion (Morton et al. 2006, Nepstad et al. 2009), while one fifth has been for crop expansion. Most of the latter (84\%; Wright 2009) has been for soy, the vast majority of which has been in the Cerrado. When soy is processed, only $18 \%$ by weight is oil and the rest seedcake, which is largely exported to USA and Japan for cattle feed. Of the oil, a large part is used in margarine and other food products, the proportion at any time depending on spot prices for edible soy oil and the national fuel blending mandates in force. To meet Brazil's biodiesel targets (5\% of the national biodiesel mix by 2010), the equivalent of about $35 \%$ of current soy oil production is said to be needed (Hall et al. 2009). However, this is an overestimate as animal fats 
and oils from other oil bearing plants are also used to some extent, accounting for about $19 \%$ of the total today, although this is likely to fall in the coming decade as soy becomes even more dominant in the biodiesel sector. From this, estimates of the burden of deforestation attributable to biodiesel can be made, using different methods of calculation (Table 1). The high end estimate is $5.9 \%$, but more realistic estimates are in the range $1-3 \%$.

Table 1. The burden of deforestation due to biodiesel in Mato Grosso

\begin{tabular}{|c|c|c|c|}
\hline & Factor & $\begin{array}{l}\text { Range of } \\
\text { estimates }\end{array}$ & Source/notes \\
\hline A & $\begin{array}{l}\text { Forest clearance attributable to } \\
\text { cultivation (remaining } \\
\text { clearance is due to grazing) }\end{array}$ & $16-20 \%$ & $\begin{array}{l}\text { Morton et al. } \\
(2006) ; \text { Nepstad } \\
\text { et al. (2009) }\end{array}$ \\
\hline $\mathrm{B}$ & $\begin{array}{l}\text { Soy as percentage of total } \\
\text { cultivation area (ignoring } \\
\text { double cropping) }\end{array}$ & $84 \%$ & Wright (2009) \\
\hline $\mathrm{C}$ & $\begin{array}{l}\text { Oil as percentage of soy crop, } \\
\text { by weight }\end{array}$ & $18 \%$ & \\
\hline $\mathrm{D}$ & $\begin{array}{l}\text { Oil as percentage of soy crop, } \\
\text { by market value }\end{array}$ & $42 \%$ & $\begin{array}{l}\text { Based on 3:1 } \\
\text { ratio of } \$ / \text { tonne } \\
\text { (World Bank } \\
\text { 2008) }\end{array}$ \\
\hline $\mathrm{E}$ & $\begin{array}{l}\text { Percentage of soy oil required } \\
\text { to meet Brazil's biofuel } \\
\text { blending targets }\end{array}$ & $35 \%$ & Hall et al. (2009) \\
\hline $\mathrm{F}$ & Forest loss due to soy & $13.4-16.8 \%$ & $\mathrm{~A} \times \mathrm{B}$ \\
\hline $\mathrm{G}$ & $\begin{array}{l}\text { Forest loss due to soy oil, by } \\
\text { weight }\end{array}$ & $2.4-3.0 \%$ & $\mathrm{~F} \times \mathrm{C}$ \\
\hline $\mathrm{H}$ & $\begin{array}{l}\text { Forest loss due to soy oil, by } \$ \\
\text { value }\end{array}$ & $5.6-7.0 \%$ & $\mathrm{~F} \times \mathrm{D}$ \\
\hline $\mathrm{J}$ & $\begin{array}{l}\text { Range of estimates of forest } \\
\text { loss due to biodiesel based on } \\
\text { weight and } \$ \text { values }\end{array}$ & $0.8-2.6 \%$ & $\begin{array}{l}\text { Min. G x E, max. } \\
H \times \text { E }\end{array}$ \\
\hline $\mathrm{K}$ & $\begin{array}{l}\text { Alternative estimate of forest } \\
\text { loss due to biodiesel, based on } \\
\text { economic inseparability of soy } \\
\text { oil and soy meal }\end{array}$ & $4.6-5.9 \%$ & $\begin{array}{l}\text { F x E; burden } \\
\text { calculated on } \\
\text { total soy crop, } \\
\text { not on oil only. }\end{array}$ \\
\hline
\end{tabular}

\section{Evidence of the social impacts of soy}

Regarding the social impacts of soy cultivation for biofuel, it is to be expected that any shift from small-scale subsistence farming to large-scale commercial production will result in loss of livelihoods for some while generating employment for others. The key question is to what extent different local stakeholders have been affected positively or negatively by the agricultural changes that have taken place over the last 30 years in the soy growing areas. The first point to establish is that in the Cerrado areas at least, there were no indigenous or peasant populations present before they were opened up in the 1960s, unlike the situation in Sao Paulo state for example where large areas of smallholder land were taken over for sugar and ethanol production (Fernandes et al. 2010). The earliest settlers in the main soy belt in Mato Grosso were cattle rearers and loggers. Bickel and Dros (2003), expressing the concerns of a number of NGOs, note that for the Mato Grosso area employment levels on large mechanized soy farms are low (about 1 permanent worker per 500 hectares). Importantly however, this is more per hectare than in the low intensity cattle ranching that soy has replaced.

There are concerns too about the form of employment; according to Bickel and Dros (2003), 723 cases of slavery were registered in farms in this area in 2002. Typically, slavery occurs when a hired contractor, known as a gato, recruits impoverished men from the slums of large cities or poor, rural villages. By offering cash up front and the promise of decent wages, he is able to entice them to leave their homes for work on a distant estate, where they are informed that they are in debt for the costs of transportation, food provided on the trip, and even tools. The debts are never erased; the illiterate workers have little recourse, and are thus enslaved (Campbell 2008). Bickel and Dros also claim, based on media reports, that the number of landless people and urban poor was increasing in 2003. Fearnside (1999) and Carvalho (1999) note that large-scale plantations displace people by buying out smallholders, mostly cattle rearers, who in turn clear cheaper land to the north, a movement which clearly leads to indirect deforestation. An analysis of the turnover in land reform settlements also suggests that the initial settlers sell out to others with more capital, often in a process by which land is consolidated into larger parcels (Ludewigs et al. 2009). But as Weinholt et al. (2010) point out, it is also possible that at least some of these displaced farmers get absorbed into the local economy, if not directly in the agricultural supply chains, then in the wider urban service sector which has without a doubt boomed in the last fifteen years. Using extensive municipal level data on household incomes over time, this study found that within the Legal Amazon as a whole there was no statistical evidence for an overall increase in poverty in areas where soy was being grown; in some areas increased poverty was associated with soy expansion while in others the reverse was observed. While there were some indications of increased rural inequality with soy expansion, this was not found to be statistically significant. Moreover, there was a strong increase in median rural incomes, though not in median urban incomes.

\section{Evidence for social inclusion through the PNPB}

A major goal of the PNPB is to engage family farmers in soy and oil seed production for biodiesel and as noted, there has been considerable critique of this in the literature. Hall et al. (2009) provide a general discussion on the difficulties that the program has faced, from the point of view of companies and smallholders, and conclude that it is of benefit to both sides. The goal was to engage 200,000 families; the social case for 
Fig. 1. Location of study areas. Source: Base map from Natural Earth (http://www.naturalearthdata.com)

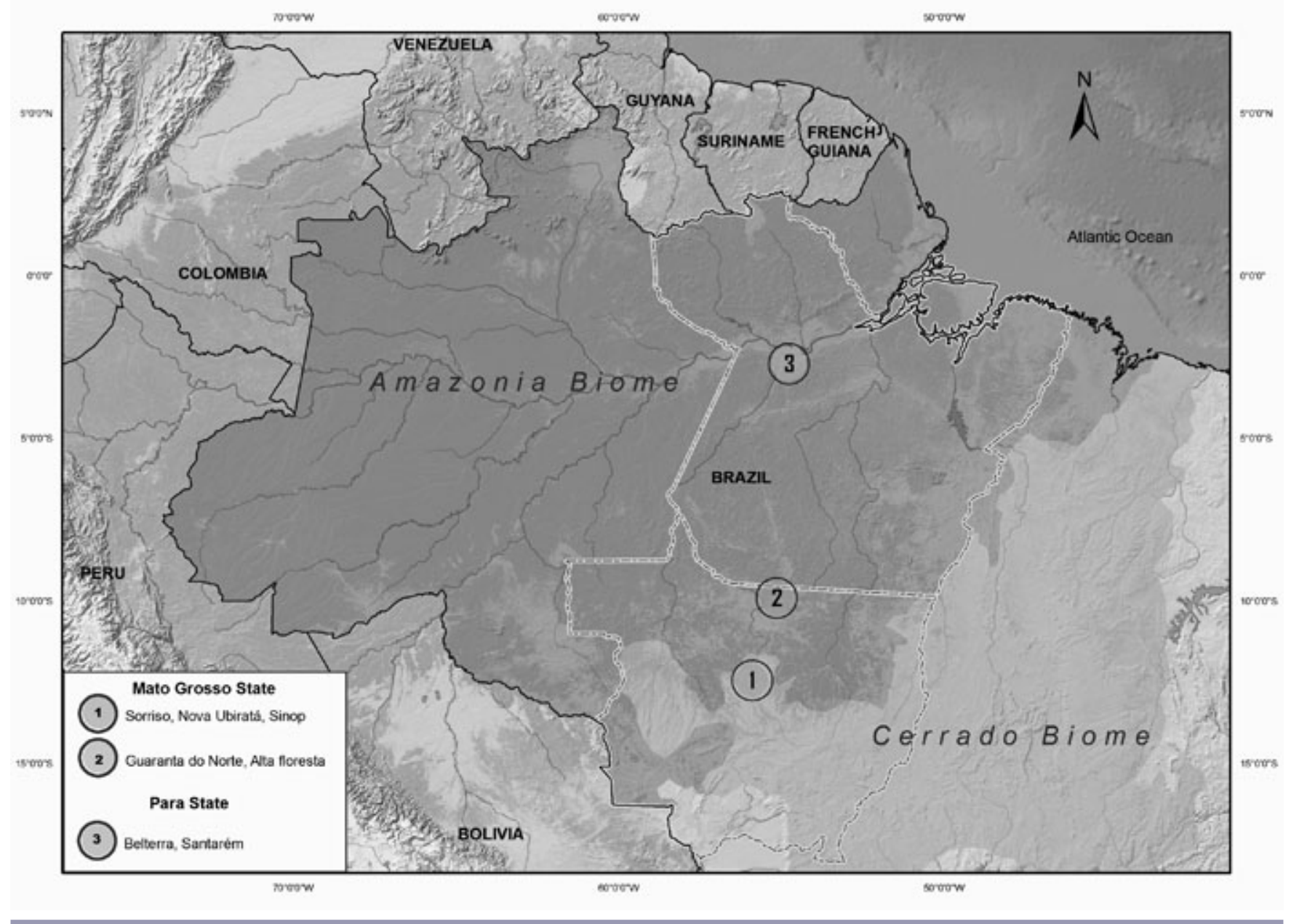

this policy has been strongly argued by Abramovay and Magalhães (2007) and so far, around 100,000 family farmers have been involved in the program. However, more recent accounts indicate that current enrolment has fallen to 37,000 (Wilkinson and Herrera 2010), partly because castor oil production in north and northeast Brazil has proven uneconomic and the companies ceased purchasing it in 2008; prior to that time, castor represented $61 \%$ of the biofuel feedstock plantation area of family farmers, compared to $29 \%$ for soy (Abramovay and Magalhães 2007). Hospes and Clancy (2011) also note the failure to draw in sufficient small farmers and show that the proportion of oils produced by this group is well below the target. Other authors point to the vulnerability of family farming for biofuel feed stocks, since profitability depends totally on the auction system, which may be subject to political change at any time (Wilkinson and Herrera 2010). Garcez and de Souza Vianna (2009) have pointed out that small farmers may not be able to negotiate fair contracts, given the power of the multinationals involved, and Hospes and Clancy (2011) take this argument further, suggesting that this may be the reason why so many decline to participate (deliberate self-exclusion). Wilkinson and Herrera further suggest that a system of cooperatives would be needed to encourage more family farmer involvement. In Mato Grosso, family farm soy production takes place mainly on agrarian reform settlements; there are said to be about 2,700 such farmers involved (Wilkinson and Herrera 2010).

\section{METHODS}

In the case study, we further explore these impacts at the level of the farms and the farmers. Research was conducted in farms in the States of Pará and Mato Grosso, along the axis of the BR 163 highway connecting southern Mato Grosso (Cuiabá) to western Pará (Santarém). Three areas with distinct characteristics were selected for the study. The first area is in the orbit of Sorriso, in the Cerrado biome, where soy has been 
well established since the mid 1980s. Here interviews were carried out in farms in the municipality of Sorriso itself, including the agrarian settlements of Santa Rosa and Cedro Rosa, as well as in Nova Ubiratã and around Sinop. The second area is located in northern Mato Grosso (Guarantã do Norte and Alta Floresta), in the transition area on the edge of the Amazon biome, where a very limited amount of soy is cultivated but an increase is anticipated in the coming years. The third area, around Santarém and Belterra, is fully in the Amazon biome. This area was selected for the study because it is another frontier in the expansion of soybean, and here there have been reports of volatile social relations between customary land users and migrant soybean producers (Greenpeace 2006). The locations of the three sites are shown in Figure 1.

\section{Characteristics of the areas studied}

Sorriso, founded only in 1987, has quickly grown in both population and wealth, with a 2009 population of 60,000 and a per capita income of nearly U.S.\$15,000 (IBGE 2007, 2009). This makes Sorriso one of the wealthiest municipalities in Brazil, ranked first in income from agriculture nationally. Located in the Cerrado biome, rapid in-migration by soy farmers from southern Brazil, driven by government policy and spontaneous land transactions, caused a large-scale shift from native vegetation to soy and other agricultural crops. Expansion of soy in the 1980s and 1990s brought about massive deforestation of the area around Sorriso, including Nova Ubiratã and Sinop. Today, the landscape consists of large, highly mechanized soybean farms, many covering thousands of hectares. From October to February soybeans stretch as far as the eye can see, replaced by maize in the alternate season. There is no natural vegetation along farm boundaries or between fields. The only remnants of the original vegetation are found in riparian zones and near water bodies (APPs). There are no longer any areas to be cleared, although small deforestation events can be observed in the riparian forest remnants. These forest areas are isolated and disconnected, preventing gene flow between populations of wild flora and fauna, and many show signs of recent burning. Livestock is minimal and mostly occupies areas that are otherwise unsuitable for soybean, including waterlogged areas or slopes, which prevent mechanization.

Guarantã do Norte in northern Mato Grosso was founded in 1981. It has a per capita income of R $\$ 5,550.00$ (about U.S. $\$ 3,200$ ) (IBGE 2007), and is thus considerably less wealthy than Sorriso. It is the most northerly city in the state of Mato Grosso on highway BR 163 and the main economic activity is cattle ranching on small properties, mostly resulting from a colonization project of the federal government through the INCRA. There is very little soybean cultivated in this area due to the costs of production and particularly of transportation (R\$3 or U.S.\$1.20 per 60kg sack to the warehouses of Sorriso). With the paving of the BR 163, however, the economics of soy will change, and the relatively low cost of freight to and from the port of Santarém (Cargill) may encourage planting in Guarantã do Norte. Lack of regularization of land tenure for many farmers may still prevent access to bank credit for most producers, but the population has watched developments in Sorriso and is very receptive to soy cultivation. Alta Floresta, a town of about 50,000, is $100 \mathrm{~km}$ west of Guarantã do Norte. It was founded in 1976 and has a per capita income of about R\$ 8,000 (U.S.\$4,700) (IBGE 2007), being more isolated than Guarantã. Since its foundation the area has gone through several economic cycles, but cattle rearing is now at the heart of its economy and this is reflected in the fact that the total herd in 2007 was 748,850 (FAMATO and FABOVE 2007). Before livestock, there were unsuccessful attempts to grow coffee, guarana (Paullinia cupana), coconut, cocoa, and citrus fruits. The city also experienced a gold rush in the $1980 \mathrm{~s}$ and in 1990 there was a timber boom. There is still forest in the region, although the timber trade has been curtailed to a great extent by strengthened government regulation of extraction. The city is located within the "arc of deforestation", a region between the states of Pará, Mato Grosso and Rondônia where deforestation rates are higher than elsewhere in the Amazon. There has been loss of $52 \%$ of coverage of the original vegetation in just over three decades (Michalski et al. 2008).

Santarém is a municipality at the confluence of the Tapajós and Amazonas rivers, with a per capita income of $\mathrm{R} \$ 5,750$ (U.S.\$3,300) (IBGE 2007). The city emerged as a village in 1661 and attained the rank of city in 1848 through various economic cycles (1637: cocoa, 1810-1915: cane sugar; 1860-1915 and 1920-1945: rubber; 1950: jute; 1970: federal highways; 1960-1993: gold rush). It has thus had a completely different history compared to the other two regions studied, and it is clear that deforestation may have much older roots than soy (Webb 2002). In the twentieth century occupation of the region occurred in waves following the economic cycles, with immigrants coming mainly from the northeast of the country. Many also came to the region to escape a long period of drought in the northeast in the 1980s. Most migrants took up subsistence farming and today there are 220 rural settlements, mainly in the Planalto Santareno, where the municipality of Belterra is located. This plateau is a region of drier light soil that is well suited to mechanized agriculture. However, more than 500,000 hectares of this plateau have become badly degraded. Family farming is characterized here by a traditional system of slash-and-burn, without mechanization, fertilizers or pesticides, on landholdings of about 75 hectares. In the past the swidden cycle was 10 to 20 years, but today it has been reduced to six to seven years. The resulting secondary vegetation, capoeira, is similar to that found in other Amazonian regions brought under cyclical agriculture (Perz and Walker 2002, Metzger 2003). When the gold rush ended, the economy of the region stagnated. The 
Table 2. Characteristics of soy farms in the sample

\begin{tabular}{|c|c|c|c|c|c|c|c|c|c|c|c|}
\hline Farmer group & Location & $\begin{array}{l}\text { Area } \\
\text { farm } \\
\text { (ha) }\end{array}$ & $\begin{array}{l}\text { Area } \\
\text { under } \\
\text { soy }\end{array}$ & $\begin{array}{l}\text { Area } \\
\text { under } \\
\text { pasture }\end{array}$ & $\begin{array}{l}\text { Area } \\
\text { refor- } \\
\text { ested }\end{array}$ & $\begin{array}{l}\text { Natural } \\
\text { forest }\end{array}$ & $\begin{array}{l}\text { Use of land } \\
\text { before soy }\end{array}$ & $\begin{array}{l}\text { Perm. } \\
\text { workers }^{\dagger}\end{array}$ & $\begin{array}{l}\text { Temp. } \\
\text { workers }\end{array}$ & $\begin{array}{l}\text { Bags } \\
\text { soybean } \\
\text { per ha }\end{array}$ & Second crop \\
\hline \multirow[t]{6}{*}{$\begin{array}{l}\text { Medium/small } \\
\text { size, open } \\
\text { market }\end{array}$} & Sorriso & 3600 & 2600 & 80 & 17 & 900 & $\begin{array}{l}\text { Cerrado, } \\
\text { followed by } \\
\text { one year of } \\
\text { rice }\end{array}$ & 7 & 0 & 55 & $\begin{array}{l}\text { maize, } \\
\text { sunflower }\end{array}$ \\
\hline & $\begin{array}{l}\text { Guarantã } \\
\text { do Norte }\end{array}$ & 1035 & 710 & - & - & 325 & Cattle/ & 5 & 10 & 60.5 & maize \\
\hline & Sorriso & 687 & 450 & - & - & 237 & Cattle & 1 & 1 & 63 & maize \\
\hline & Sorriso & 650 & 500 & 3 & - & 147 & $\begin{array}{l}\text { Cerrado, } \\
\text { followed by } \\
\text { one year of } \\
\text { rice }\end{array}$ & 2 & 0 & 63 & maize \\
\hline & $\begin{array}{l}\text { Nova } \\
\text { Ubirata }\end{array}$ & 545 & 400 & 30 & & 115 & Cerrado & 0 & 2 & 65 & maize \\
\hline & $\begin{array}{l}\text { Guaranta } \\
\text { do Norte }\end{array}$ & 250 & 150 & 75 & - & 25 & $\begin{array}{l}\text { Cerrado, } \\
\text { followed by } \\
\text { rice }\end{array}$ & 0 & 0 & 60 & maize \\
\hline \multirow{4}{*}{$\begin{array}{l}\text { "Landless" } \\
\text { (agrarian } \\
\text { reform) } \\
\text { farmers under } \\
\text { PNBP }\end{array}$} & $\begin{array}{l}\text { Sorriso } \\
\text { (S. Rosa) }\end{array}$ & $100^{1}$ & 66 & - & 3 & $30^{1}$ & Cattle & & & & maize \\
\hline & $\begin{array}{l}\text { Sorriso } \\
\text { (S. Rosa) }\end{array}$ & 100 & 70 & - & - & 30 & Cattle & 0 & 0 & 55 & maize/beans \\
\hline & $\begin{array}{l}\text { Sorriso } \\
\text { (S. Rosa) }\end{array}$ & 100 & 70 & - & - & 30 & Cattle & 0 & 0 & 50 & maize/beans \\
\hline & $\begin{array}{l}\text { Sorriso } \\
\text { (S. Rosa) }\end{array}$ & 100 & 70 & - & - & 30 & Cattle & 0 & 0 & - & maize \\
\hline
\end{tabular}

$\dagger$ Note: in addition to family labor

alternative pursued by the state government was the introduction of soybean, encouraging producers from Mato Grosso to acquire land in the region and supported by research conducted by EMBRAPA (the Brazilian Enterprise for Agricultural Research), which developed soybean varieties adapted to the region (EMBRAPA 2005, 2006).

\section{Approach to the survey}

In each of these localities, interviews were undertaken with four categories of respondents affected in different ways by these developments. A total of 17 key informants (managers of agro-processing plants, agricultural researchers, government officials in the land reform sector, etc.) were first approached with a view to obtaining their perspectives on the situation. Thereafter, interviews were held with soybean farmers $(n=10$, of which 4 were family farmers with micro-holdings $(<100$ ha) and 6 had small to medium sized farms (250-5,000 ha); rural households not involved with soybean cultivation $(n=14)$; and those employed on soybean farms $(n=11)$. Note that we did not carry out interviews on larger farms because owners are rarely present. Interviews were conducted using a semi-structured interview schedule prepared separately for each group. The interviews were designed to obtain information on the link between soybean cultivation and deforestation, the loss of forest goods and services (particularly wood products such as firewood, and water regulation capacity) resulting from any observed deforestation, and the perceived socioeconomic impacts (positive and negative) associated with soy cultivation. It is clear that the size of this sample is too small for any meaningful statistical analysis to be carried out; the research is in the form of a scoping study, with the purpose of identifying trends and issues that were of concern to the different stakeholder groups. Particular attention has been paid to understanding the opportunities and problems of small-scale soy producers in relation to biofuel. Main results are shown in Tables 2 and 3. 
Table 3. Perspectives of soy farmers, other farmers and laborers on impacts of soy

\begin{tabular}{|c|c|c|c|}
\hline Perceptions & $\begin{array}{l}\text { Soy farmers } \\
(\mathrm{n}=10)\end{array}$ & $\begin{array}{c}\text { Other farmers } \\
(\mathrm{n}=14 ; \\
\text { cattle } \\
\text { rearers }=12, \\
\text { subsistence }=2)\end{array}$ & $\begin{array}{c}\begin{array}{c}\text { Laborers } \\
(\mathrm{n}=11 ;\end{array} \\
5 \text { permanent, } \\
6 \text { temporary) }\end{array}$ \\
\hline \multicolumn{4}{|l|}{ Effect of soy on income } \\
\hline •very positive & 6 & $7^{\dagger}$ & 11 \\
\hline •positive & 4 & 6 & \\
\hline -negative & & 1 & \\
\hline \multicolumn{4}{|l|}{ Access to food } \\
\hline •negative effect & & 1 & \\
\hline •no effect & & 6 & \\
\hline -positive effect & 10 & 7 & 11 \\
\hline \multicolumn{4}{|l|}{ Quality of life } \\
\hline \multicolumn{4}{|l|}{ 1.Housing } \\
\hline -Improved & 9 & 8 & 11 \\
\hline -Decreased & 1 & 1 & \\
\hline -No change & & 5 & \\
\hline \multicolumn{4}{|l|}{ 2.Social infrastructure } \\
\hline •Improved & 10 & 11 & 11 \\
\hline -Decreased & & 1 & \\
\hline -No change & & 2 & \\
\hline \multicolumn{4}{|c|}{ Conflicts in the community } \\
\hline •Increased & & $\mathrm{n} / \mathrm{a}$ & \\
\hline -No change & 7 & & 5 \\
\hline •Don't know & 3 & & \\
\hline \multicolumn{4}{|c|}{ Impacts on the environment } \\
\hline \multicolumn{4}{|l|}{ 1. Soil erosion due to soy } \\
\hline •More & 1 & 4 & 1 \\
\hline •None & 9 & 5 & 4 \\
\hline -Don't know & & 5 & \\
\hline \multicolumn{4}{|l|}{ 2. Water quality } \\
\hline -No change & 9 & 6 & 5 \\
\hline •Decreased moderately & 1 & 4 & \\
\hline -Decreased & & 2 & \\
\hline significantly & & 2 & \\
\hline \multicolumn{4}{|l|}{ •Don't know } \\
\hline \multicolumn{4}{|l|}{ 3. Agricultural pests } \\
\hline •No change & 5 & 6 & \\
\hline •Increased & 5 & 3 & 5 \\
\hline •Don't know & & 5 & \\
\hline \multicolumn{4}{|l|}{ 4. Loss of forest services } \\
\hline •Yes & & 1 & \\
\hline •No & 10 & 13 & 5 \\
\hline
\end{tabular}

Notes

$\dagger$ : This figure refers partly to farmers' perceptions of income if they were able to start cultivating soy, but also to the availability to them of well-paid jobs in other sectors, and to the fact that soy has increased the price of land, meaning that their property is appreciating. $\ddagger$ : All laborers are skilled mechanics or drivers; there are no manual laborers on the soy farms

$\S$ : Six laborers were not able to answer the questions on changes in conflict in the community and changes in environmental status as they moved to the area to work and cannot compare to the earlier situation.

\section{FARM LEVEL SURVEY FINDINGS}

\section{Sorriso: the Cerrado zone \\ Production systems}

The soy farming system in this part of the Cerrado is highly industrialized and mechanized to allow large-scale production with low labor inputs. The large agricultural machines (harvesters, sprayers) are purchased on credit from banks, many of which are subsidiaries of the equipment companies, backed by Brazilian government finance. Pesticides and herbicides are applied using large sprayers on smaller farms (up to $5000 \mathrm{ha}$ ) or by light planes on the larger ones, accounting for about $20 \%$ of the costs of production. Most produce is sold to large multinationals such as Cargill, Bunge, and Louis Dreyfus, or to the Brazilian soy giant Amaggi. A typical 5000 ha farm may employ as few as 10 permanent workers and 15 temporary workers for particular operations; these are skilled machine operators as there is no manual labor involved. The daily wage for temporary laborers is R $\$ 35$ or about U.S.\$20, plus meals and coffee four times per day, which is culturally significant in the Brazilian context. They also earn a bonus related to the size of the harvest. Some farms are family owned and others belong to large agro-processing companies. Permanent workers benefit from a variety of side benefits including housing on the estate.

In addition to this predominant farming model there are the small-scale family farmers on the INCRA settlements, who are referred to by the mainstream farmers as "landless people". In terms of land area, they form a tiny fraction of the total. Economies of scale mean that these farmers cannot compete in soy production without considerable financial and technical support. Some settlements have been "adopted" by the soy purchasing companies because of the PNPB program, and receive special attention, including interest-free loans to purchase equipment and inputs, even above-market prices for their soybeans; these subsidies are provided by the companies because they need to meet their quotas from family farms in order to participate in the national biofuel markets, as intended by the PNPB policy. In these settlements, our interviews indicated that there is a considerable turnover and hidden consolidation of landholdings, driven by the relative high levels of income generated through economies of scale, and resulting in incipient class formation. However the companies 
are very selective in their support. Settlements in which land is broken up by water courses, or which is too hilly for largescale machinery, and settlements in which individual holdings are much less than 70 hectares are not usually of interest to the companies as the unit costs are so high. In these less well endowed settlements, very little soy is grown. Instead, the smallholders cultivate a variety of subsistence crops or use the land for grazing, and much of it appears to be abandoned. Some gain income from casual labor on the commercial farms. The cases of Santa Rosa and Cedro Rosa illustrate these two conditions (see Appendices 1 and 2).

\section{Perceived environmental and social impacts}

On the question of whether the market for biodiesel has increased deforestation, none of the rural respondents in our survey felt able to make any statement, because they do not sell their soybeans specifically for biofuel, but to companies which purchase the crop for a variety of products. Some had cleared the Cerrado, but the majority claimed that the land had been used for grazing previously, although it may be noted that grazing land is often partially covered with secondary forest regrowth, particularly if it has been abandoned for some years. The question of loss of forest goods and services was not considered relevant by most soy farmers, who live very modern lifestyles, even in the agrarian settlements, with electricity and gas for cooking. In the non-soy agrarian settlements, there was evidence of secondary forest regrowth on many plots, as these were underutilized for agriculture, and here firewood was being used as well as bushmeat. Other plots had been cleared for timber but not further utilized. In these settlements there was no perception of loss of services over time, mainly because the settlers are themselves newcomers.

On the question of social and economic well-being as a result of biodiesel, all but one of the farmers interviewed, both large and small, stated clearly that soy has brought enormous benefits to the region in terms of wealth generation, although the role of biodiesel in stimulating prices was not well understood. The non-soy farmers in agrarian settlements recognize the economic benefits of soy to the region even if they do not grow soy directly; many have gained employment on the larger soy farms, or seen their property values increase. The availability of urban services (education, health, entertainment, shopping) was cited by many as a positive development related to soy. Moreover, all respondents in the survey in this area reported an increase in income over the last few years. For the case of the agrarian settlers, this finding has to be understood in the context of their previous lifestyles. Many of them were originally from the timber industry, which was being steadily reduced. Others came from impoverished agricultural areas in the south of the country or from low income jobs in cities.

What is missing from this account is the fact that an unknown number of cattle farmers have been displaced by the arrival of soy in the region. Cattle ranches cannot compete economically and their owners must either switch to soy or move to other areas, a process which may well bring about indirect deforestation elsewhere and which may also cause social dislocation. We also noted that some agrarian settlers had sold their lots to a second wave of settlers; they have also moved on, but this study was not able to ascertain what their situation is now.

\section{Guarantã do Norte and Alta Floresta: the transition zone \\ Production systems}

Soy is grown by only a small number of farmers in Guarantã and is virtually nonexistent around Alta Floresta at present, with only two farms that started in 2005. Several factors contribute to the lack of soybeans here. The first is the strong tradition of ranching and an economy geared to extensive cattle raising, reflected in the presence of several beef packing industries in the region. The second is the logistics that soybean require, not only good roads for the delivery of inputs and for the transport of the crop, but also presence of bridges on the farms capable of supporting heavy weights, and warehouses for storage. From Alta Floresta the cost of transporting a 60 $\mathrm{kg}$ bag of soy to Sorriso is $\mathrm{R} \$ 3.50$ (or U.S.\$2), which is higher even than from Guarantã and makes Alta Floresta a very uncompetitive location.

\section{Perceived environmental and social impacts}

In this transition region we were not able to interview many soy cultivators or even soy laborers, as they are extremely scarce. However, our sample included a variety of key informants and cattle farmers who would be the first in line to switch their land to soy were it to become economically feasible in this area. These respondents were unanimous in their response as regards the impact of future soy production on forests. Each one independently mentioned the recent policy of the federal government inhibiting illegal deforestation, and reducing the eligible clearance to $20 \%$ of any parcel. This was cited as the main constraint on soy expansion and on deforestation. However, soy is considered an excellent means for the recovery of degraded pastures, a strategy that is being strongly pushed in various parts of Brazil by EMBRAPA (Wilkinson and Herrera 2010). The majority of the respondents plan to rent part of their land on a seasonal basis to small and medium soy producers, keeping an estimated $30 \%$ of open area for livestock, which would be partly reared using stall feeding. However, it is likely that some will sell land to soybeans farmers and either start local businesses or move to other states, although in this context respondents spoke only in terms of returning to their home states. We encountered no individuals who said they planned to buy cheaper lots in the forests to the north, but this may well have reflected the perception of respondents that this would not have been a socially acceptable response to the question. 
The debate on deforestation, launched mainly by Greenpeace some years ago, has been effective in raising awareness of positions in this respect, if not wholehearted support for the idea.

In terms of social impacts, the question is theoretical since soy has scarcely arrived in this zone yet. However, it was noticeable that respondents in our survey unanimously considered soybean a synonym for income generation and employment. Soy is considered in a very positive light and "rightly or wrongly" is expected to boost incomes, food security, social life, housing quality, and social infrastructure.

\section{Santarém: the Amazon biome \\ Production systems}

Soy cultivation in this area is limited, though whether this is due to Greenpeace's campaign or not is open to debate. The total area under soy reached 28,000 hectares in 2007-2008, compared to over 5 million hectares in Mato Grosso in the same period. It represents only $5.6 \%$ of the 500,000 hectares already degraded by family farmers in the Planalto Santareno (SIRSAN personal communication). In 2009 there were only 142 soy farmers in the Santarém area, with a total of 26,000 hectares under soy and 7,000 hectares under rice, an average of 232.4 hectares per producer. The largest farmer has 1,600 ha in total and is considered by the soybean industry as a small producer. All this production represents only $3 \%$ of the movement through Cargill's port. One of the most important reasons for the limited development is the lack of formal land tenure of most farmers which makes it impossible for them to obtain credit.

\section{Perceived environmental and social impacts}

According to respondents in our survey, soy producers in this region are recent immigrants (since 1996), comprising mostly former employees of soybean producers in Mato Grosso who came to Santarém because of the opportunity to acquire land at low cost (one hectare costing on average R $\$ 150$ or U.S. $\$ 85.70)$. The first areas were purchased from dealers in Santarém who practiced farming and sold their properties in response to the economic crisis of that period. These areas were interesting because they were already open (deforested). In 2001 there was a new stimulus for the planting of soy in the region, the construction of a grain handling port for Cargill in Santarém. The new wave of incoming soybean cultivators turned to areas degraded by farming families on the Planalto Santareno, which is where most of the soy is cultivated today. This involved clearing the capoeira or secondary forest fallow, which was much easier than felling mature forests. Many local residents reportedly sold their properties to such newcomers. Although they were thus "displaced", our interviews indicated that they were not coerced into leaving their land. A hectare of land was soon selling for R $\$ 1,000$ (U.S.\$572), and most purchasing agreements seem to have been conducted amicably. The settlers who sold their land apparently intended to go to cities or towns that offered basic infrastructure such as schools, energy, and medical care, or to new projects of agrarian reform, which would in some cases increase pressure on the primary forest, although in this study we were not able to establish whether they had successfully made such moves. We were informed that some had found jobs in mineral projects near Santarem. A few in our sample had sold most of their land but retained a small strip that contained their house and enough area for subsistence planting. The sale of lots, coupled with the expansion of soybean, caused the Union of Rural Workers of Santarém (STRS) in 2005 to promote a campaign called "Do not give up your land." In 2006 the movement sought the cooperation of Greenpeace, after which the matter escalated to the international arena. Today the price of land has stabilized. Though there is still land on offer, it seems that soy producers are no longer interested in moving to this area.

The campaign that Greenpeace launched (Greenpeace 2006) stated that the production of soy for biodiesel among other elements was driving illegal deforestation in the Amazon biome, the illegal occupation of the governmental lands, and violence against local communities. The staff of the Rural Union of Santarém (SIRSAN), representing the farmers, acknowledged in our interviews that there had been some exaggeration of the threat of deforestation. In hindsight it appears that in fact $92 \%$ of areas planted before 2004 came from areas already cleared by 1999 and only $8 \%$ from removal of primary forest, with only $2.7 \%$ clearance of primary forest in 2004-2005. Over the past 30 years $26,453 \mathrm{~km}^{2}$ of forest were lost in the municipalities of Santarem and Belterra, of which $597 \mathrm{~km}^{2}$ were converted directly into areas of mechanized agriculture $(2.22 \%), 3,023 \mathrm{~km}^{2}$ to pasture $(11.43 \%), 6,772 \mathrm{~km}^{2}$ to secondary forest $(25.60 \%)$ and 16,070 $\mathrm{km}^{2}$ into areas of family and medium sized farms $(60.75 \%)$ (Venturieri et al. 2007). This concurs with the results of our survey, in which respondents did not associate soy cultivation with deforestation in this area at all.

There is also some doubt about how much conflict took place. Bickel and Dros (2003) state that the cultivation of soybean leads to a concentration of land and a rural exodus, but according to our interviews in Santarém, it was the absence of positive public policies and rural social infrastructure that discouraged the earlier settlers from remaining. The arrival of soybean presented an opportunity to escape these conditions. Isolated conflicts are, however, reported both by soybean producers and environmentalists. In our interviews, we came across one case in which a settler sold the same lot several times to prospective soybean farmers and one case in which a soybean farmer denied access to a road across his property that was formerly used by the local people. Although such incidents have been reported by both sides, all 142 remaining soybean farmers have proof of purchase and sale of their farms. 
The Rural Union recognizes that Port Cargill may induce a slight expansion of soybean production, but considers that this will be minimal. Ironically it is the lack of land regularization in Pará state (only 5\% of the land in Santarém is documented) that discourages larger scale production. Access to credit is a major part of this, as Cargill provides credit only within the Program on Responsible Soy and the Soy Moratorium, which involves zero deforestation. To be part of this, the producer has to have full paperwork for his land and prove that he is within the environmental regulations. The 142 soybean producers currently operating in the Santarém area comply with this, which indicates the importance of international policy initiatives like the one promoted by Greenpeace in establishing sustainability.

\section{CONCLUSIONS}

World demand for soybeans for food and cattle fodder is inducing increased production in Brazil and the domestic demand for biodiesel will augment this. However, as we have shown, only a very small part of the total soy production is devoted to biofuel. We estimate that the direct deforestation due to biodiesel in Mato Grosso is in the range 1 to 6\%, a small but identifiable part of the total. In addition, there is certainly some indirect deforestation as a result of displaced cattle raising, both within the Cerrado and further to the north, although the dynamics of indirect land use change are highly complex, and often involve several steps such as rice cultivation; we were not able to assess them within the scope of this study. Around $80 \%$ of the direct deforestation in Mato Grosso, however, is due to grazing and the rest to other uses of soy and to other crops. The vast majority of the clearance for soy has been in the Cerrado (savanna) zone of the state, not in the humid forests. In Pará, within the Amazon biome, despite the opening of Port Cargill at Santarém, the rate of deforestation for soy has in recent years been heavily constrained by government restrictions on forest clearance, as well as the low suitability of most of the area for soy, and the fact that many properties do not have formal land tenure and so cannot easily access bank credit. In the transition area and in the Amazon biome, soybean is more likely to expand to areas already cleared for cattle raising, and respondents in our survey indicated that the most probable model would be a lease system in which part of the holdings currently used as grazing land would be leased to soy cultivators for one or two seasons. This has the effect of renewing degraded pastures and increasing the productivity of cattle ranches through intensification and crop-livestock integration, a policy that is being strongly promoted by EMBRAPA (Landers et al. 2005).

The influence of multi-stakeholder processes on regulating the loss of forest, particularly the Soy Moratorium, has been considerable, since this was able to bring the major purchasing companies, the banks, and the government into line. The strongest instrument here was the refusal of banks to give credit to soy growers who had cleared illegal quantities of forest on their plots, and the availability of satellite imagery made it possible for banks to check this easily.

The current situation may soon be modified, however, as a result of amendments to the Brazilian Forest Code which are under consideration by the Brazilian Congress at the moment. Driven essentially by rising international demand for soymeal, these would relax some of the restrictions on forest clearance and give impunity to many illegal deforesters. In anticipation of this, deforestation rates peaked in the first half of 2011, particularly in the Mato Grosso soy and cattle belt, and although such sharp increases are unlikely to be sustained since they represent a one-off opportunistic response to the policy uncertainty, any policy that makes clearance for agriculture easier is bound to result in losses of forest to soy in the long run. Whether it will open up forest areas to more small farmers is debatable; that would depend more on the policy of INCRA in its choice of locations for agrarian settlements.

International attention on deforestation in Brazil tends to focus on the Amazon biome. However, the loss of Cerrado forest is also of concern. Although such forests do not hold as many tonnes of carbon per hectare as rainforests, at least in their aboveground biomass, Cerrado forests contain an extraordinarily high level of biodiversity. Brazil has achieved a joining of forces between the productive sector and environmental groups to protect the Amazon biome, with strong government support. This would be a good occasion to consider greater protection of the Cerrado, even though as previously noted, biodiesel plays only a small role in this deforestation.

In terms of the social implications of loss of forest goods and services, there was no perception of such loss among our respondents, who do not in general depend directly on such services for domestic purposes. This is because not only on the commercial farms, but also in the agrarian settlements in which soy is the main crop, the lifestyle of the residents is modern (electricity, gas etc). But few even seemed concerned for environmental services provided by, for example, pollinators. While environmental certification of soy for biofuel by multi-stakeholder processes such the Roundtable on Sustainable Biofuels will be very difficult to implement, given that soy is used for so many different products, there could be a role for more general agro-environmental certification for soy, and indeed some schemes have been proposed by ABIOVE and APROSOJA. One of the functions of this could be to raise farmers' awareness of the wider environmental impacts of cultivation practices, such as on pollination. The difficulty will be to develop certification schemes that are effective but simple, and that are independently verifiable. 
Concerning impacts on income and employment, even though soy does not employ many workers per hectare, ranching employs even fewer. Moreover, the soybean chain provides many jobs in production and transportation of seeds, fertilizers and pesticides, machinery repair, drivers, etc. This is reflected in the Human Development Index (HDI) and income levels in soy municipalities. Sorriso has seen enormous growth in HDI over the last 20 years and average income is currently 4.6 times that of Guarantã do Norte, which is dominated by livestock in small farms. There is no doubt that some cattle rearing families have been displaced by the incoming soy cultivation, as we observed in the Santarém area, but our interviews with nonsoy farmers who were present at the time of the transfers indicate that the departed farmers may have regarded the possibility of selling their property as a benefit, given the minimal conditions of access to health and education that prevailed in these areas. Further studies would be needed to follow their tracks and examine both the question of indirect deforestation and their socioeconomic trajectory.

The Brazilian government has tried to promote the social inclusion of family farmers in the production of biodiesel with the Social Fuel Seal. This program is intended to assist thousands of families across the country to grow and market oil-bearing crops such as soy. In Mato Grosso a number of the agrarian reform settlements have been involved in this program, although we found that many beneficiaries were not the original occupants of the small properties donated by the government, but later arrivals with greater technical and organizational skills, and possibly more capital. Some of these families were able to consolidate holdings and, with the technical support of the large soy companies, make a good profit from what is still considered very small-scale soy production. However, the holdings as initially distributed (around 70 hectares of cultivable land per family) provide meager profits, even in the protected market developed under the PNPB. Not all agrarian settlements in the area were engaged in the program, however. Where plots were even smaller, and land was broken up by watercourses or contained hilly terrain, the production costs appear to be too high to gain the interest of the soy companies.

Responses to this article can be read online at: http://www.ecologyandsociety.org/voll6/iss4/art4/responses/

\section{Acknowledgments:}

This paper has been produced with the financial assistance of the European Union, under a project entitled, "Bioenergy, sustainability and trade-offs: Can we avoid deforestation while promoting bioenergy?" The objective of the project is to contribute to sustainable bioenergy development that benefits local people in developing countries, minimizes negative impacts on local environments and rural livelihoods, and contributes to global climate change mitigation. The project is managed by the Center for International Forestry Research and implemented in collaboration with the Council on Scientific and Industrial Research (South Africa), Joanneum Research (Austria), the Universidad Autónoma de México and the Stockholm Environment Institute. The views expressed herein can in no way be taken to reflect the official opinion of the European Union. Thanks are due to two anonymous reviewers whose insights and comments have strengthened the paper considerably. We also thank the family Machado for valuable assistance during the fieldwork in the Sorriso region.

\section{LITERATURE CITED}

ABIOVE (Associação Brasileira das Indústrias de Óleos Vegetais). 2010. Monitoring of the soy moratorium 2009/10. [online] URL: http://abiove.com.br/english/ss relatoriouso09 us. asp

Abramovay, R., and R. Magalhães. 2007. Brazil: Access of family farmers to biodiesel markets: partnerships between large companies and social movements. The Regoverning Markets Programme, Sustainable Markets Group, London, UK.

Adario, P. 2011. Brazil risks protection record by proposing changes to forest code. The Guardian, 27 May.

Amaral, W. A. N., S. Ferraz, and R. Esmeraldi. 2005. Dinâmica da soja, o desmatamento na fronteira agrícola da Amazônia. Democracia Viva (27):114-122.

Andrade, R. M. T. de, and A. Miccolis. 2010. Biodiesel in the Amazon. ICRAF Working Paper no. 113. World Agroforestry Centre, Nairobi, Kenya. http://dx.doi.org/10.5716/WP16722. PDF

ANP (Agência Nacional do Petróleo, Gás Natural e Biocombustíveis). 2010. Biodiesel. Agência Nacional do Petróleo, Gás Natural e Biocombustíveis. [online] URL: ww w.anp.gov.br/?id=472

Barona, E., N. Ramankutty, G. Hyman, and O. T. Coomes. 2010. The role of pasture and soybean in deforestation of the Brazilian Amazon. Environmental Research Letters (5) 024002. http://dx.doi.org/10.1088/1748-9326/5/2/024002

Barreto, P., C. Souza Jr., R. Noguerón, A. Anderson, and R. Salomão. 2005. Human pressure on the Brazilian Amazon forest biome. World Resources Institute (WRI), Institute for Man and the Environment in the Amazon (IMAZON), Belém, Brasil.

Bickel, U., and J. M. Dros. 2003. The impacts of soybean cultivation on Brazilian ecosystems. WWF, AIDEnvironment, Bonn, Germany. [online] URL: http://assets.panda.org/downl oads/impactsofsoybean.pdf 
Brandão, A. S. P., G. Castro de Rezende, and R. W. Costa Marques. 2005. Agricultural growth in the period 1999-2004: outburst of soybean area and environmental impacts in Brazil. Instituto de Pesquisa Econômica Aplicada (IPEA), Rio de Janeiro, Brazil.

Brown, J. C., M. Koeppe, B. Coles, and K. P. Price. 2005. Soybean production and conversion of tropical forest in the Brazilian Amazon, the case of Vilhena, Rondonia. Ambio 34 (6):462-469.

Campbell, J. 2008. A growing concern: modern slavery and agricultural production in Brazil and South Asia. Pages 131-141 in Topical research digest: human rights and contemporary slavery. University of Denver, Colorado, USA.

Carvalho, R. 1999. A Amazônia rumo ao círculo da soja. Amazônia Papers, vol. I, 2. Programa Amazõnia. Amigos da Terra, São Paulo, Brasil.

Carvalho, G., D. Nepstad, D. McGrath, M. D. C. Vera-Diaz, M. Santilli, and A. C. Barros. 2002. Frontier expansion in the Amazon: balancing development and sustainability. Environment 44(3):34-45. http://dx.doi.org/10.1080/0013915 $\underline{0209605606}$

Conte, L. 2006. Economia de escala e substituição de fatores na produção da soja no Brasil. Thesis. Universidade de São Paulo, Piracicaba, São Paulo, Brasil.

EMBRAPA (Empresa Brasileira de Pesquisa Agropecuària). 2005. BRS Carnaúba, nova cultivar de soja para a região norte e nordeste do Brasil. Comunicado Técnico 180. EMBRAPA, Teresina, Brasil.

EMBRAPA (Empresa Brasileira de Pesquisa Agropecuària). 2006. Soja BRS Candeia: comportamento e recomendação para plantio nas microrregiões de Paragominas e Santarém, PA. Comunicado Técnico 182. EMBRAPA, Belém, Brasil.

FAMATO e FABOVE (Federação da Agricultura e Pecuária do Estado de Mato Grosso e Fundo de Apoio à Bovincultura de Corte). 2007. Diagnóstico da cadeia produtiva agroindustrial da bovinocultura de corte do estado de Mato Grosso. [online] URL: http://www.fabov.com.br/arquivos/fab 0121081200939477.pdf

Fearnside, P. M. 1999. Forests and global warming mitigation in Brazil: opportunities in the Brazilian forest sector for responses to global warming under the "clean development mechanism". Biomass and Bioenergy 16(3):171-189. [online] URL: http://dx.doi.org/10.1016/S0961-9534(98)00071-3

Fearnside, P. M. 2005. Deforestation in the Brazilian Amazonia: history, rates and consequences. Conservation Biology 19:680-688. http://dx.doi.org/10.1111/j.1523-1739.2 005.00697.x
Fernandes, B. M., C. A. Welch, and E. C. Goncales. 2010. Agrofuel policies in Brazil: paradigmatic and territorial disputes. Journal of Peasant Studies 37(4):793-819. http://dx. doi.org/10.1080/03066150.2010.512459

Garcez, C. A. G., and J. N. de Souza Vianna. 2009. Brazilian biodiesel policy: social and environmental considerations of sustainability. Energy 34:645-654. http://dx.doi.org/10.1016/ j.energy.2008.11.005

Gibbs, H. K., A. S. Ruesh, F. Achard, M. K. Clayton, P. Holmgren, N. Ramankutyy, and J. A. Foley. 2010. Tropical forests were the primary sources of new agricultural land in the 1980s and 1990s. Proceedings of the National Academy of Science 107(38):16732-16737. http://dx.doi.org/10.1073/p nas.0910275107

Goldemberg, J., and P. Guardabassi. 2009. Are biofuels a viable option? Energy Policy 37:10-14 http://dx.doi.org/10.10 16/j.enpol.2008.08.031

Greenpeace. 2006. Eating up the Amazon. Greenpeace, Amsterdam, The Netherlands.

Hall, J., S. Matos, L. Severino, and N. Beltrão. 2009. Brazilian biofuels and social exclusion: established and concentrated ethanol versus emerging and dispersed biodiesel. Journal of Cleaner Production 17:572-585. http://dx.doi.org/10.1016/j.j clepro.2009.01.003

Hospes, O., and J. S. Clancy. 2011. Unpacking the discourse on social inclusion in value chains. Pages 23-41 in A. H. J. Helmsing, and S. Vellema, editors. Value chains, social inclusion and economic development: constrasting theories and realities. Routledge, London, UK.

IBGE (Instituto Brasileiro de Geografia e Estatística). 2007. Tabela 1- Produto Interno Bruto a preços correntes e Produto Interno Bruto per capita segundo as grandes regiões, Unidades da Federação e Municipios- 2002-2005. In Produto Interno Bruto dos municípios 2002 - 2005. Instituto Brasileiro de Geografia e Estatística. [online] URL: http://www.ibge.gov.br/ home/estatistica/economia/pibmunicipios/2005/tab01.pdf

IBGE (Instituto Brasileiro de Geografia e Estatística). 2009. Estimativas da população para 1 de Julho de 2009. Estimativas da população. Instituto Brasileiro de Geografia e Estatística. [online] URL: http://www.ibge.gov.br/home/estat istica/populacao/estimativa2009/POP2009 DOU.pdf

INPE (Instituto Nacional de Pesquisas Espaciais). 2010. Confirma o desmatamento por estado e na Amazônia Legal (2001-2009). In Monitoramento da floresta Amazônica por satélite. PRODES database. Instituto Nacional de Pesquisas Espaciais. RODES Database. [online] URL: http://www.inpe. br/noticias/arquivos/pdf/prodes2009tabela1.pdf 
La Rovere, E.L., A. S. Pereira, and A. F. Somoes, 2011. Biofuels and sustainable energy development in Brazil. World Development 39(6):1026-1036. http://dx.doi.org/10.1016/j.w orlddev.2010.01.004

Landers, J. N., J. Weiss, and J. Clay. 2005. A new solution for old problems in Brazil: crop-livestock rotation with zero tillage as a sustainable land management tool. Sociedade $e$ Natureza Special Issue:661-673.

Lapola, D., R. Schaldach, J. Alcamo, A. Bondeau, J. Koch, C. Koeling, and J. A. Priess. 2010. Indirect land-use changes can overcome carbon savings from biofuels in Brazil. Proceedings of the National Academy of Science 107(8):3388-3393. http:/l dx.doi.org/10.1073/pnas.0907318107

Ludewigs, T., A. de Oliviera D’Antonia, E. S. Brondizio, and S. Hetrick. 2009. Agrarian structure and land-cover change along the lifespan of three colonization areas in the Brazilian Amazon. World Development 37(8):1348-1359. http://dx.doi. org/10.1016/j.worlddev.2008.08.018

MDA (Ministério do Desenvolvimento Agrário). 2010. Biodiesel. Ministério do Desenvolvimento Agrário. [online] URL: http://comunidades.mda.gov.br/portal/saf/programas/biodiesel

Metzger, J. P. 2003. Effects of slash-and-burn fallow periods on landscape structure. Environmental Conservation 30 (4):325-333. http://dx.doi.org/10.1017/S0376892903000341

Metzger, J. P., T. M. Lewinsohn, C. A. Joly, L. M. Verdade, L. A. Martinelli, and R. R. Rodrigues. 2010. Brazilian law: full speed in reverse? Science 329(5989):276-277.

Michalski, F., D. Norris, and C. A. Peres. 2010 No return from biodiversity loss. Letters. Science 329(5997):1282.

Michalski, F., C. A. Peres, and I. R. Lake. 2008. Deforestation dynamics in a fragmented region of southern Amazonia: evaluation and future scenarios. Environmental Conservation 35(2):93-103. http://dx.doi.org/10.1017/S0376892908004864

Morton, D. C., R. S. DeFries, Y. O. Shimabukuru, L. O. Anderson, E. Arai, F. D. B. Espírito-Santo, R. Freitas, and J. Morisette. 2006. Cropland expansion changes deforestation dynamics in the southern Brazilian Amazon. Proceedings of the National Academy of Science 103(39):14637-14641. http: //dx.doi.org/10.1073/pnas.0606377103

Myers, N., R. A. Mittermeier, C. G. Mittermeier, G. A. B. Fonseca, and J. Kent. 2000. Biodiversity hotspots for conservation priorities. Nature 403:853-858. http://dx.doi.org $\underline{/ 10.1038 / 35002501}$
Nepstad, D. C., B. S. Soares, and F. D. Merry. 2009. The end of deforestation in the Brazilian Amazon. Science 326:1201-1203. http://dx.doi.org/10.1126/science.1182108

Perz, S. G., and R. T. Walker. 2002. Household life cycles and secondary forest cover among small farm colonists in the Amazon. World Development 30(6):1009-1027. http://dx.doi. org/10.1016/S0305-750X(02)00024-4

Skole, D., and C. Tucker. 1993. Tropical deforestation and habitat fragmentation in the Amazon - satellite data from 1978 to 1988. Science 260:1905-1910. http://dx.doi.org/10.1126/sc ience.260.5116.1905

Venturieri, A., A. S. Coelho, M. C. Thales, and M. D. R. Bacelar. 2007. Análise da expansão da agricultura de grãos na região de Santarém e Belterra, oeste do estado do Pará. Pages 7003-7010 in J. C. N. Epiphanio, L. S. Galvão, and L. M. G. Fonseca, editors. Proceedings of the XIII Simpósio Brasileiro de Sensoriamento Remoto (Florianópolis, 2007). Florianópolis, Instituto Nacional de Pesquisas Espaciais, Brasil.

Vera-Diaz, M. C., R. K. Kaufman, and D. C. Nepstad. 2009. The environmental impacts of soybean expansion and infrastructure development in Brazil's Amazon. Global Development and Environmental Institute Working Paper 09-05. Tufts University, Maryland, USA.

Webb, J. L. A. 2002. Tropical Pioneers: human agency and ecological change in highlands of Sri Lanka, 1800-1900. Ohio University Press, Athens, Ohio, USA.

Weinholt, D., E. Killick, and E. Reis. 2010. Soybeans, poverty and inequality in the Brazilian Amazon. Development Studies Institute, London School of Economics, London, UK.

Wilkinson, J., and S. Herrera. 2010. Biofuels in Brazil: debates and impacts. Journal of Peasant Studies 37(4):749-768. http: //dx.doi.org/10.1080/03066150.2010.512457

World Bank. 2008. Commodity price data. [online] URL: http://siteresources.worldbank.org/INTDAILYPROSPECTS/ Resources/Pnk 1008.pdf

Wright, A. M. 2009. Sustainability and agriculture in the state of Mato Grosso. Brazil Institute, Woodrow Wilson International Centre for Scholars, Washington, D.C., USA. 


\section{Appendix 1. Soy production in an agrarian settlement}

Santa Rosa, at Boa Esperança, is about $130 \mathrm{~km}$ from Sorriso. It was formerly a 110,000 ha estate used mostly for low intensity grazing, with considerable forest cover, went bankrupt in the 1990s. INCRA purchased 80.000 ha; the other 30,000 had been invaded illegally by settlers who had already cut a large part of the forest. They are still fighting for legal rights. The 80,000 was divided such that approx one third has been kept under forest (the continuous area along the river) while the rest was divided into holdings of 70 ha and distributed to landless families in 1998. Simple houses were built of breeze block by INCRA and financial assistance for clearing the forested areas was provided.

Within two years, at least half of the lots in Santa Rosa had changed hands. Social classes of different levels of wealth and power can be seen to develop. For example, in 2000, $\mathrm{H}$. purchased five adjacent lots, one for himself and one each for his adult sons,, from 5 separate original settlers. This gives them a total of 300 ha (though the separate titles for each son that means individually they all fall within the cutoff for 'Small Farmers "). Some of the original settlers have been able to expand their holdings by buying others (eg family S.). These families get a lot of assistance from agro-processing companies involved in the PNPB to purchase agricultural machines and the company also provides credit for the seeds and pesticides etc. which is repaid at harvest time. After paying off the debt, farmers are not required to sell the remainder of the crop to the company but the company offers a premium price because it needs to purchase as much as possible from small farmers in order to participate in government auctions, The $\mathrm{H}$. family use their large machines to provide services to farmers who have less land and no machines, payment for these services helps to pay off their credit (for example, they harvest for the family V, who purchased their lot from the original settler in 2002). Family $\mathrm{S}$ were able to purchase a smaller harvester on a shared basis with a neighbor. Family V., which has only one lot, has two tractors and sells tractor services to other farmers who have no machines at all, such as the family $\mathrm{C}$. However, even the poorest families like $\mathrm{C}$. do receive credit (for seeds, fertilizer and pesticides) from the company and also get the premium price for their crop. However, unlike the other farmers, they do not cultivate a second crop of maize, presumably because they do not have the capital for this (they cultivate just a very small area of maize, 5 ha, which is to feed the few livestock they keep).

The distinctions of wealth are plain to see in the level of professionalism and organization of the farms. The most successful and well-off are consolidating land and earning from services provided to others. They generally have a good educational background and technical and management know-how; their constraint earlier had been lack of capital to purchase land, which has been overcome through the agrarian reform programme and the PNPB. Then there is a much poorer class who survive because of support prices and technical assistance given for the soy crop, but who are clearly not accumulating wealth. They lack management and organisational skills and the farms are marginal; they not able to invest, The differences are easy to see in the housing, with the former families living at middle class standards, with all mod cons, while the poorer farmers live in a more traditional style. In addition, there is the unseen class of farmers who have left, after being bought out by farmers such as $\mathrm{H}$. They were not able to make a go of the farming here at all. However, all the farmers who have remained in Santa Rosa, even the poorest, were very positive about their soy production and about the support they receive from the company, not only the premium prices they obtain, but also the access to credit. 
Appendix 2. An agrarian settlement not producing soy

Cedro Rosa is another agrarian settlement, around $60 \mathrm{~km}$ from Sorriso and adjoining some large soy farms. Here the lots are much smaller (around $40 \mathrm{ha}$ ) and the land is also more broken up (water courses, slopes, etc.). Like Santa Rosa it had been a bankrupt grazing estate, purchased and divided up by INCRA, and like Santa Rosa this involved a considerable amount of forest clearance, although the individual lot holders are each supposed to maintain a forest reserve. It is evident this rule that has not been followed by all the settlers. These farms are too small for economic soy production, and so the agro-processing industries are not interested in helping these farmers. They are used instead for manioc, some maize, and a few cattle. They are largely operated at very low levels of productivity, and there is some forest re-growth on many of the lots because the land is not tilled. The standard of housing indicates that the settlers are rather poor. Many of the settlers work as casual laborers (drivers) on the neighboring large farms. 